\title{
Just a Scrap of History: Judge Cassius Gaius Foster and Major J.K. Hudson, "The Fighting Editor"
}

\section{M.H. Hoeflich*}

\section{INTRODUCTION}

In a shady spot in the Topeka Cemetery is to be found the last resting place of Cassius Gaius Foster. The grave is marked by a small, tasteful, gray stone monument, which gives little hint of the tumultuous life lived by the man buried beneath. ${ }^{1}$ Few remember Judge Foster today, but during the last quarter of the nineteenth century he was the sole representative of federal justice in Kansas. ${ }^{2}$ He was also one of the most controversial figures of his era, the scourge of temperance advocates across the state, and a litigant in one of the nastiest and most bizarre cases in Kansas in the nineteenth century.

Cassius Gaius Foster was born in upstate New York in $1837 .^{3} \mathrm{He}$ went to school there and in 1859, he entered the law office of a local attorney in Rochester to read law with the hope of joining the Bar and becoming a practicing attorney. ${ }^{4}$ But Foster soon realized, as did so many young lawyers and law students of his era, that the Bar in the northeastern states was crowded and that it would be difficult to make a living. And, thus, he took Horace Greeley's famous advice, "Go west, young man," to heart and traveled to Atchison, Kansas to live and work. ${ }^{5}$

\footnotetext{
* John H. \& John M. Kane Professor of Law, University of Kansas School of Law. This article is a version of a chapter that will appear in the forthcoming sesquicentennial history of the Federal District of Kansas, of which I am author, which will be published for the court by the Kansas City Star in 2011.

1. See Find A Grave, Cassius Gaius Foster, http://www.findagrave.com/cgi-bin/fg.cgi? page $=$ gs \& (enter "Cassius Gaius Foster" in the "Name" search fields; then follow "Foster, Cassius Gaius" hyperlink) (last visited Mar. 8, 2010).

2. See Federal Judicial Center, Judges of the United States Courts, Foster, Cassius Gaius, http://www.fjc.gov/public/home.nsf/hisj (follow "F" hyperlink; then follow "Foster, Cassius Gaius" hyperlink) (last visited Mar. 8, 2010) [hereinafter FJC: Foster].

3. Id.

4. See id.

5. See id.
} 
In 1859, when Foster settled in Atchison, it was a frontier town. The era of "Bleeding Kansas" was coming to an end, but the clouds of war hung ominously over the whole nation. ${ }^{6}$ The city had been founded in July 1854 by a group led by Senator David R. Atchison of Missouri. ${ }^{7}$ The city at this time, and for three years following, was a pro-slavery stronghold. ${ }^{8}$ Indeed, in 1855 , the citizens took out their anger against the abolitionist cause by expelling the Reverend Pardee Butler, an outspoken opponent of slavery, by tying him to a log raft and setting him adrift on the Missouri River. ${ }^{9}$ In the same year, a band of Atchison men took part in a raid on Lawrence, the Free State capital. ${ }^{10}$ But within the next two years, the Free State forces in Kansas were politically victorious and the citizens of Atchison decided to give up their pro-slavery politics and concentrate on building the city's economy. ${ }^{11}$ Quite quickly, the business community grew and prospered. By 1859, the year of Foster's arrival in Atchison, the biggest political issue was not slavery, but road improvements. ${ }^{12}$

It seems Foster settled quickly and successfully into the Atchison community. He practiced law full-time from 1859 until 1863 when he was elected to serve as a state senator. ${ }^{13}$ He returned to private practice in 1864 and was elected Mayor of Atchison in 1867..$^{14}$ Once again, in 1868 , he returned to his law practice and remained in that position until 1874 when he was nominated by President Ulysses S. Grant, at the age of 37, to serve as Federal District Judge for the District of Kansas. ${ }^{15}$

Foster had two predecessors on the federal bench in Kansas: Archibald Williams, who served only from 1861 to $1863,{ }^{16}$ and Mark

6. See Nicole Etcheson, Bleeding Kansas: Contested Liberty in the Civil War ERA 217-18 (2004).

7. See History of the State of Kansas Containing a Full account of its Growth FROM AN UNINHABITED TERRITORY TO A WEALTHY AND IMPORTANT STATE; OF ITS EARLY SETTLEMENTS; ITS RAPID INCREASE IN POPULATION AND THE MARVElous DEVELOPMENT OF ITS Great Natural Resources. Also, a SupPlementary History and Description of its

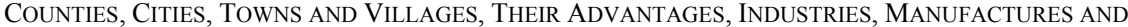
Commerce; to Which are Added Biographical Sketches and Portraits of Prominent Men AND EARLY SETTLERS 369 (1883).

8. Id.

9. Id. at $371-72$.

10. Id. at 372 .

11. See id. at 373 .

12. See id.

13. FJC: Foster, supra note 2.

14. Id.

15. $I d$.

16. Federal Judicial Center, Judges of the United States Courts, Williams, Archibald, http://www.fjc.gov/public/home.nsf/hisj (follow "W" hyperlink; then follow "Williams, Archibald" 
Delahay, who served from 1864 to $1873 .{ }^{17}$ Williams' tenure ended by illness and death. ${ }^{18}$ Delahay resigned under threat of impeachment and renewal as a result of his drunkenness on and off the bench. ${ }^{19}$ Interestingly, Foster was also quite ill during much of his quarter-century on the bench and did not produce a large number of decisions. ${ }^{20}$ However, while his judicial productivity was low, he was extremely active in the fight against prohibition in Kansas. Indeed, during much of his time as a judge he was most deeply involved as a vociferous opponent of prohibition. ${ }^{21}$ This opposition led him to become one of two parties in a series of widely publicized cases in the Kansas state courtsparticipation which made him one of the most infamous Kansans of his era.

\section{The Kansas Prohibition Movement}

Robert Smith Bader, author of the standard work on the history of the prohibitionist movement in Kansas, has pointed out that many of the emigrants who came to Kansas during the territorial period came with twin political goals. ${ }^{22}$ The first, of course, was to ensure that Kansas would be a free state without slavery. ${ }^{23}$ The second was that Kansas be a "dry" state. $^{24}$ Once the battle over slavery was won, the battle over prohibition began.

To a large extent, the political controversy over prohibition in Kansas grew out of several factors. First, as a frontier state, and one with too many cowboys and too few lawmen, Kansas was a rough place in which drinking, gambling, and prostitution were prevalent. ${ }^{25}$ Second, as the state became more civilized, more families moved into Kansas and

hyperlink) (last visited Mar. 9, 2010) [hereinafter FJC: Williams].

17. Federal Judicial Center, Judges of the United States Courts, Delahay, Mark W., http://www.fjc.gov/public/home.nsf/hisj (follow "D" hyperlink; then follow "Delahay, Mark W." hyperlink) (last visited Mar. 9, 2010).

18. FJC: Williams, supra note 16.

19. The Federal Courts of the Tenth Circuit: A History 23 (James K. Logan ed. 1992), http://10thcircuithistory.org/pdfs/1992_historical_book/4Chapter2.pdf.

20. H.R. REP. NO. 55-1716, at 1 (1899). His most important decision also involved alcoholic beverages in Indian territory. See William E. Unrau, United States v. Downing, Judge Cassius Gaius Foster and the Sale of Spirituous Liquors to Indians In Indian Country, in THE LAW AND LaWyers in Kansas History: A Collection of Papers Presented at the 116Th ANNual MeEting OF THE KANSAS STATE Historical SOCIETy OCTOBER 4 \& 5, 1991, at 1, 10-12 (1992).

21. Robert SMith BAder, Prohibition In KANSAS: A History 107-08 (1986).

22. Id. at 15 .

23. $I d$.

24. $I d$.

25. See id. at 17-20, 24. 
while the men might well have been willing to tolerate a "wild west" society, the women settlers wanted a more civilized and tranquil environment in which to live and raise their children. ${ }^{26}$ Indeed, even during the territorial period, the prohibition movement gained strength and supporters in the northeastern part of the state. As early as 1856, a group of Topeka women petitioned the territorial legislature to ban the sale or importation of liquor and other alcoholic beverages. ${ }^{27}$ In the summer of that year, a group of women, armed with hatchets, attacked a saloon in Lawrence, a communal activity which soon became common. ${ }^{28}$

There were, however, certain impediments to the burgeoning temperance and prohibitionist movement. The first - and greatestimpediment was that Kansas women had no general right to vote in elections, other than for school boards. ${ }^{29}$ Although the subject of women's suffrage was raised at the Wyandotte Convention in 1859, in spite of vigorous arguments on behalf of women's rights, the Convention chose to give only very limited suffrage to female Kansans. ${ }^{30}$ However, while women could not themselves vote in favor of prohibitionist legislation, they could do everything in their power to force their husbands and male relatives to support their cause. And this they did. Over the next three decades, women would lead the charge-with eventual success - for prohibition. ${ }^{31}$

The second impediment to passing prohibitionist legislation in Kansas was a combination of geography and demography. During the first decades of statehood, western Kansas remained very much a frontier with cattle as the primary industry. Saloons and drinking were an integral part of the "cowboy way." 32 Even in northeastern Kansas there was a split. In Lawrence, Topeka, and Emporia, where the population was dominated by emigrants from the northeastern states, prohibitionist feeling was strong. ${ }^{33}$ But in Leavenworth and Atchison counties, where the population was dominated by emigrants from Germany, the situation

\footnotetext{
26. See id. at 16 .

27. Id.

28. Id. at 17

29. See id. at $20-21,99$.

30. See id. at 21

31. Id. at $16-18$.

32. See id. at 23 (stating that the saloons of the cow-towns could be found "emitting a memorable odor of ... [a] blend of liquor, tobacco, straw, horses, and kerosene").

33. See id. at 19-20 (stating that certain events, "especially Quantrill's Raid of 1863, served to plant the temperance flag firmly on the Free State side of the question").
} 
was quite different. ${ }^{34}$ To put it bluntly, the German emigrants were not willing to give up their beer or their beer halls. ${ }^{35}$

As a result of these factors, much of Kansas politics in the 1860s and 1870 s was focused on the prohibition question. The tide turned in favor of statewide prohibition only when John Pierce St. John was elected governor on the Temperance and Republican tickets. ${ }^{36}$ St. John had come to Kansas in 1869 and settled in Olathe to practice law. ${ }^{37}$ Very quickly, St. John also became known for his good looks (which no doubt helped gain him votes), his oratory, and his strong temperance and views. ${ }^{38}$ He did not, however, campaign on the prohibition issue. ${ }^{39}$

Once St. John assumed the governorship, the stage was set for a serious political push for prohibition. A young member of the Kansas Christian Temperance Union from Fort Scott, J.R. Detwiler, convinced his fellow "KCTU" members that the best strategy to follow in their fight was to push for a constitutional amendment rather than legislation. ${ }^{40}$ Petitions were circulated and presented to the legislature in January $1879 .{ }^{41}$ The legislature voted to support a state referendum on the issue in a particularly close vote in which many members switched from one side to the other. ${ }^{42}$ The "dry" and "wet" forces lined up against each other and a massive political campaign on the amendment ensued. ${ }^{43}$ Northeastern Kansas, border counties, and the German population stood against the amendment. ${ }^{44}$ The vast majority of other Kansans favored the amendment. ${ }^{45}$ Certainly, there were some respected political leaders who opposed the amendment. ${ }^{46}$ The most notable was Charles Robinson, former governor and hero of the Free State struggle. ${ }^{47} \mathrm{~A}$ second notable opponent was Judge Cassius Gaius Foster, Federal District Judge for the District of Kansas. ${ }^{48}$

\footnotetext{
34. See id. at 21-22.

35. Id. at 22 .

36. Id. at 37-39.

37. Id. at 37

38. Id.

39. Id. at 39 .

40. Id. at 40-41.

41. Id. at 41 .

42. Id. at $43-44$.

43. Id. at 44-45.

44. Id. at 44 .

45. Id. at 44-45.

46. Id. at 48 .

47. See id.

48. Id. at 107-08.
} 
The vote on the prohibition amendment took place in $1880 .{ }^{49}$ It passed by a small margin. ${ }^{50}$ As one would expect, it had little support in western Kansas and in the German-dominated counties of Leavenworth, Atchison, Doniphan, Barton, and Wyandotte. ${ }^{51}$ In 1881, the legislature passed enabling legislation, and on May 1, 1881, Kansas became a "dry" state. $^{52}$ Although the prohibitionists had won their amendment, the issue was far from dead. For the next ten years, debate and conflict over the "dry" status of Kansas continued. There were even minor riots against prohibition. ${ }^{53}$ Most importantly, in those counties and cities which had opposed the amendment, enforcement was difficult, if not impossible. ${ }^{54}$ The anti-prohibition forces continued to find ways of avoiding the provision, and the temperance forces continued to pressure the governor, the legislature, and city and county officials to increase enforcement. Although prohibition was in force, a thirsty man could still get a drink in most parts of Kansas.

The ongoing battles over enforcement of prohibition consumed Kansas politics during the 1870s. The anti-prohibitionists soon came to be the "resubmissionists": those who favored a revote on the constitutional amendment. ${ }^{55}$ The resubmissionist movement gained increasing strength and during the 1880 s and 1890s debates-political and social — raged on. ${ }^{56}$ Just as Judge Foster had been a champion of the anti-prohibitionist forces in the $1870 \mathrm{~s}$, he became one of the leaders of the resubmissionist movement of the $1880 \mathrm{~s}$ and $1890 \mathrm{~s}^{57}$

There is no evidence that Judge Foster himself was a frequenter of saloons, nor is there any indication in the record that he overindulged in alcohol. Instead, it would seem that Judge Foster's position on prohibition had both philosophical and historical roots. Foster spent his early years in Kansas in Atchison, where his political career began. Atchison, as a German community, was among the leaders against prohibition. $^{58}$ Second, by his own words, Judge Foster was troubled at the philosophical and political implications of government intervention

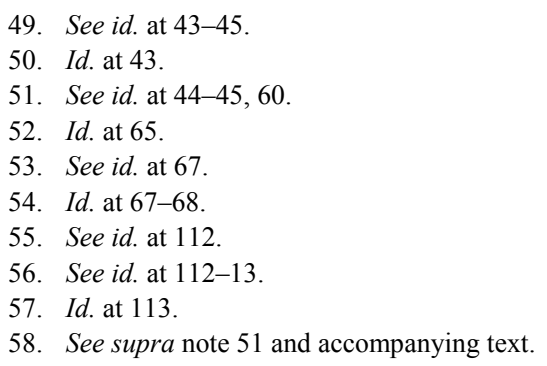


in the private lives of its citizens. ${ }^{59}$ To Judge Foster, the moral arguments against easy availability of alcoholic beverages were far outweighed by his sense of personal liberty and opposition to governmental regulation of private activities. There is absolutely no reason to doubt Foster's motives. ${ }^{60}$

Beginning with the earliest territorial years, newspapers in Kansas were the most powerful political voices in the state's public discourse. ${ }^{61}$ During the 1870s and the run-up to the 1881 prohibition law, almost two hundred newspapers allied themselves with the temperance and prohibitionist movement. ${ }^{62}$ The Topeka Daily Capital was in the forefront among these. ${ }^{63}$ Its editor was Major J.K. Hudson. ${ }^{64}$

J.K. Hudson was born and raised in Ohio. ${ }^{65}$ His father was the editor of an anti-slavery newspaper. ${ }^{66}$ In 1861, Hudson traveled to Kansas and joined the Third Regiment of the Kansas Volunteers, known as "Lane's Brigade," after James K. Lane. ${ }^{67}$ He was mustered out in 1865 and moved to Wyandotte County. ${ }^{68}$ In 1871 , he was elected to the Kansas House of Representatives, and in 1873, he made an unsuccessful run for United States Congress. ${ }^{69}$ Later that year he published a newspaper, The Kansas Farmer, and resettled in Topeka. ${ }^{70}$ In 1879, he started the Topeka Daily Capital, which he edited for the next several decades. ${ }^{71}$ Hudson was a crusading newspaperman and one of his many causes was the temperance and prohibition movement. ${ }^{72}$ According to one

59. See The Legal and Political History of the Suits Brought by Hon. Cassius Gaius Foster, Judge of the U.S. District COURT of Kansas, Against Maj. J.K. Hudson, Editor Daily Capital, of Topeka, Kansas: Giving the Origin, Facts, LetTers, Charges, INDICTMENTS, EDITORIALS, AND DECISIONS OF THE CASES OF 1890 AND 1895, at 7 (1895) [hereinafter THE LEGAL AND POLITICAL HISTORY].

60. Id.; see also Cecil Howes, Pistol Packin' Pencil Pushers, 13 KAN. HIST. Q. 133-34 (1944).

61. William E. CONNElley, History of Kansas NewsPapers: A History OF THE

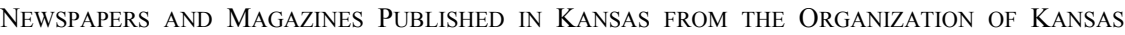
TERRITORY, 1854, TO JANUARY 1, 1916 TOGETHER WITH BRIEF STATISTICAL INFORMATION OF THE COUNTIES, Cities AND TOWNS OF THE STATE (1916), available at http://www.kshs.org /research/topics/kansasnewspapers/KansasNewspapersPreface.htm.

62. BADER, supra note 21 , at 57.

63. Major J.K. Hudson, NATiOnal MAgazine: MAgazine of Western History ILLUSTRATED (1894), at 50.

64. Id.

65. Id.

66. Id.

67. Id.

68. Id.

69. Id. at 51

70. Id.

71. Id.

72. Id. 
biographer, Hudson was known "for the vigorous style of his work" and by another as "the fighting editor." "73 This was, as will become clear, a remarkable understatement. In 1890, Major Hudson and Judge Foster entered into a public battle in which both displayed the "vigor" of their voices. $^{74}$

\section{The BATtLe Between Foster AND Hudson Begins}

The beginning of the battle between Hudson and Foster started innocently enough in 1889 . Judge Foster was called upon to speak at a Resubmissionist rally. The following was reported by Hudson and the Daily Capital:

\section{RESUBMISSION RALLY AT THE GRAND OPERA HOUSE.}

On December 28, 1889, after a season of much advertising, a great state rally of the resubmissionists was held at the Grand opera house, in Topeka. Invitations had been sent to all the cities of the state, and special railroad rates secured. A dozen speakers were announced from Leavenworth, Wichita, Topeka, and elsewhere. In point of numbers and ability the meeting was a great failure. Judge Foster, it had been announced, would preside and make a speech. From the Daily Capital, of December 29, we take the following account of Judge Foster's speech:

Judge Foster, when introduced, said that his election as chairman of this convention was entirely unexpected. He was glad to see so many visitors from abroad, and said: "I desire to say on the part of at least one-half of the people of this city, who are not cranks and intolerants, that you are welcome; yes, thrice welcome. We have been inflicted with disquisitions and speeches from various gentlemen, from the governor down to the young attorney who, having nothing else to do, sits down and interviews himself, and has the interview published in the newspapers." The Judge then became rather humorous, and thought that a law prohibiting the sale of feather beds, because some people were lazy and were not early risers, would be as reasonable as the law prohibiting the sale of liquor. The feather-bed story was concluded at 8:40 o'clock. "They tell us," said Judge Foster, "that money spent for liquor is thrown away; but don't we spend money foolishly in many other ways? Whoever thought of passing a law declaring how men shall or shall not spend their money?" The Judge said that he believed that four times as many men are killed every year by the use of tobacco as by the use of liquor, and yet, said he, you will

73. Id.

74. See The Federal Courts of the Tenth Circuit, supra note 19, at 24 . 
see these rabid prohibitionists going around with a quid of tobacco in their mouth as big as a goose egg. "I don't wish at all to be understood that I am in love with the saloon. Liquor men are inclined to be aggressive; they are inclined to overstep the bounds of propriety, but the traffic may be regulated."

While it would appear that Judge Foster's speech may not have been an oratorical masterpiece, Major Hudson's response to the speech was a bit harsh and insulting:

\section{EDITORIAL COMMENTS FROM DAILY CAPITAL ON JUDGE FOSTER'S SPEECH.}

Those who are training the Judge for senator are greatly chagrined by his failure at his first appearance on the platform and in type. They say that he was n't "at himself." So it seems to the people.

The people have a right to be indignant when a judge, instead of using argument, scolds them in bad English. Judge, if you must abuse your neighbor, leave out slang, and give us good grammar. ${ }^{76}$

Hudson's printed attack on Foster drove the Judge into a frenzy and, unfortunately, Judge Foster at that point decided to elevate the dispute from a war of words and turn it into a legal battle. ${ }^{77}$ The path he took was unwise in the extreme. First, the legal basis for Foster's charges was shaky. ${ }^{78}$ Hudson's newspaper had been used for years to print legal notices of matters in the District Court. Suddenly, Judge Foster discovered that the litigants had been overcharged for the notices and that too few notices had been run. ${ }^{79}$ Thus, he decided to do two things: take the legal notice business away from the Daily Capital and, also, require Hudson to repay the so-called "overcharges":

A few days ago my attention was called to the alarming fact that you have for years past been systematically disregarding the act of congress and the orders of this court in publishing these notices. Instead of publishing them six times, as the law and the order itself required, you have stopped on five publications, and hurried in your bill for a fee at least three times the amount allowed you by law. Titles to a vast amount of real estate have been based on these defective notices, and are absolutely worthless. How can you, Major Hudson, say you are

\footnotetext{
75. The Legal And Political History, supra note 59, at 7.

76. Id.

77. See id. at 9 .

78. See infra note 96 and accompanying text.

79. The LEgAL AND POLitiCAL History, supra note 59, at 9.
} 
not guilty of gross carelessness and culpable negligence in this matter? Every day this court is now called upon to set aside decrees and titles by reason of your blunders. Ask your attorney if you are liable for damages to the injured party. It is not for me to decide.

You will be given a chance to explain these charges in court, for an order will be made retaxing the printer's fees in every case for the past two years, there being over 40 cases. Any balances ascertained to have been wrongfully drawn from the registry of the court by you will be ordered returned within a stated time.

Perhaps it might be well for you to understand beforehand that your zeal in the cause of prohibition will not be received as any reason why you shall not comply with the law; nor need you fear that your unfair treatment of the circuit and district judges of this court, for many years past, will in the least influence the court in dealing out to you evenhanded justice. ${ }^{80}$

Most politicians and judges have learned that it is very unwise to attack the press unless one's charges are absolutely iron-clad. Not only is the press protected by the First Amendment, but an attack on one newspaper tends to be a clarion call to all newspapers to come to the defense of the one attacked. Knowing this, Major Hudson was unwilling to bow down to Judge Foster. Instead, like a toreador waving his red cape in front of a crazed bull, Major Hudson raised the heat of his rhetoric against Judge Foster:

My dear Judge, your condescension is something to be grateful for; it marks a red-letter day in my history, and it gives the people an opportunity to take a look at the practical working of your judicial brain, for which all will be duly thankful. There are dogs and dogs, my dear Judge, and we have known large ones that looked fierce but only barked. I appreciate the honor you have conferred on me by breaking your extraordinary record, and hope to convince you that it would have been much wiser had you maintained that judicial silence which has so long passed for wisdom. When you condescend to a newspaper discussion, you are necessarily compelled to say something, and there are wicked people, my dear Judge, who will rend your ermine, so to speak, if you fail to talk sense and to make a good case - a danger that does not menace you on the bench, where you may be a tyrant or a fool, and none dare to question your right to be either, for you are there for life. The generous missionary spirit which prompts you to make this very, very bad break in your beautiful record for my benefit, displays at

80. Id. 
once an exalted and noble quality of mind and heart which will surprise your most intimate friends.

... These are the fees that have been charged for notices in Judge Foster's court for over 15 years, and their legality has never been questioned. These are the facts out of which Judge Foster makes his case.

And now as to the responsibility: Is it possible, Judge Foster, that with your presumed knowledge of the law, you have permitted these illegal fees to be charged in your court for over 15 years, invalidating titles and involving untold expense and litigation? Has the judge no responsibility? If you are ignorant of the law, why did you not come out like a man and say so, and not hide behind a weak and cowardly insinuation that I will be held responsible for the excess of legal fees, and given a stated time in which to return them? Is the clerk of your court not informed as to the legality of fees charged and paid by him? The notices in this paper for your court have been published and charged for as your clerk directed. Is he not responsible also? What are the attorneys who practice in your court doing for their clients that they permit illegal fees to be charged against their clients? Are the attorneys who have witnessed these fees charged for 15 years free from responsibility? My dear Judge, don't you see how dangerous it is to rush into print after 15 years' silence? Don't you wish your missionary zeal had not run away with your stupid discretion?

But this is not all. If this irregularity has been going on in your court for over 15 years because you were not informed as to the provisions of the law, does it not raise a fair presumption that your lack of information may not stop with this one blunder? You arraign a publisher for charging what your own clerk directs him to charge, and threaten him with litigation, all of which poorly covers the bad case you make for your self and the lack of legal information you yourself have had on the subject. Every publisher, every lawyer and every man of common sense knows that legal publications are printed just as often as they are ordered by the lawyers or the clerk or whoever orders them. No publisher would do otherwise. The bills are not rushed into the court as Judge Foster states, as they are never settled until the cases are completed, a fact that our condescending and humorous Judge is probably not familiar with.

Proceed with the prosecution for illegal fees, my dear Judge. My defense I am willing to give to you now. It will be something like this: "Your honor, I knew no more about the legal printers' fees than you did, which was less than nothing; no more, your honor, than your clerk, and no more than all the lawyers who practice at your bar. And while I know that ignorance of the law is no plea to make in an ordinary court, there seems to be so $d-d$ much of it in your court that I shall offer it, and throw myself upon your missionary sympathy." 
Your working out of a problem of printers' fees in detail will not take attention from the fact that your new love for mathematics does not clear you of the responsibility of this irregularity. You ought to have reached this little sum in multiplication about 15 years ago. ${ }^{8}$

In another Daily Capital editorial on January 12, 1890, Hudson continued:

\section{TO JUDGE CASSIUS GAIUS FOSTER.}

It has not been my intention to further expose your lack of legal information and your political pettifogging mind to the people of Kansas, because, in common with all citizens, I have a high respect for the judiciary. The courts form the great bulwark of American liberty, and are the safeguards of justice to the citizen. The people will tolerate with patience for a long time a man upon the bench who fails in the measure of his duty as a just judge rather than utter a harsh criticism upon him or his methods. What the people expect of the judge is that he honor the position that honors him.

You, as United States circuit judge, saw proper in your letter addressed to me on January 8 to charge me with having collected illegal fees for printing notices sent from your court for publication in the Capital, and to threaten me with a prosecution which must be tried in your court. You have the very distinguished honor of being, in all human probability, the first United States circuit judge in this part of the country to threaten a private citizen with litigation as a revenge for political differences of opinion, when the trial must be heard by himself. It is a spectacle that has made the people in this community, without regard to party or political opinion, discuss the importance of an impeachment trial at which you would appear as the defendant.

I did not intend to again address you upon the subject, believing your better judgment would prevent you from carrying out the threat contained in your letter of January 8. In this I was mistaken. I received at the hands of the bailiff of your court the following document:

In the circuit court of the United States, for the district of Kansas Topeka, Kas., January 9, 1890.

Whereas, it has been made to appear to this court that there has been illegal and extortionate printing fees, charged in the following cases, it is therefore ordered that the clerk of this court, on Tuesday, the 14th day of January, 1890, proceed to retax the printer's fees in said cases, according to the rates allowed by law, and that notice of this order be served on J. K. Hudson at least three days before the said retaxation:

81. Id. at $9-10$. 
Cases Nos. 5495, 5328, 5930, 5892, 6008, 5340, 5976, 5355, 6030, $5507,5686,5641,5792,6206,6192,6160,6161,6152,6186,6141$, $6142,6007,5945,6001,5758,6365,6188,6189,6261,6274,6303$, 6338 , and 6359. It is further ordered that the clerk proceed to ascertain and report to this court all cases in which the service of publication on nonresident defendants is illegal for want of proper publication.

United States of America, district of Kansas, ss.:

I, George F. Sharitt, clerk of the circuit court of the United States of America for the district of Kansas, do hereby certify the foregoing to be a true, full and correct copy of an order of said court, from the record thereof.

In testimony whereof, I hereunto set my hand and affix the seal of said court, at my office in Topeka, in said district of Kansas, this 9th day of January, A. D. 1890.

GEO. F. SHARITT, Clerk. $(\text { Seal. })^{82}$

By the time Foster had actually had his clerk, George Sharritt, produce a court order to retax the legal notice fees and require Hudson to appear in the District Court, all semblance of propriety and dignity had disappeared from the dispute. Kansas newspapers now treated Foster as a fool, a drunkard, and the Devil himself. Hudson delighted in publishing the negative comments of his brother editors. The following appeared in the Daily Capital on January 19, 1890:

\section{JUDGE FOSTER.}

The Overwhelming Testimony Against Him from the Republican Press of Kansas.

Here's Your Verdict, Judge.

His Condemnation as a Politician, as a Lawyer, and as a Judge.

A Resub.--Submitted.- - Lost.

A Reply to His Prostitution of Judicial Power Such as no Man Ever Received.

Burn the Next Letter.

82. Id. at 11 . 
Condemnation of His Conduct Crystallizes in a General Demand that He Resign.

"I Will Skin that Editor."

The Republican Press of Kansas Represents the Sentiments of the People.

The Skinner Skunned.

The Proof that no Man is Beyond the Reach of Public Sentiment.

Dinna Ye Hear the Slogan?

The Testimony of an Indignant People Against a Judge Dragging the Judicial Ermine Through the Slums of Saloon Politics.

Again, the Daily Capital ran similar statements on January 26, 1890:

\section{THE VERDICT}

Of the People of Kansas, as Shown in the Capital, January 19, and Today, is

Against Cassius Gaius Foster.

As a Judge, as a Lawyer, and as a Politician.-The Sentiment is Overwhelming,

And the Demand is, Resign.

Never Before in the History of Kansas has any Public Officer Received Such General Condemnation.

The Verdict is In, and We Rest Our Case.

Nobody is Fooled on the Legal Fees.-All See the Real Issue in this Contest.- Judge

Foster for the Saloon; the Capital Against It. ${ }^{84}$

On January 7, 1890, Judge Foster made an order requiring all legal publications to be printed in the new resubmission daily, the Topeka

83. Id. at 18 .

84. Id. at 29 . 
Republican, which was at that date exactly seven days old. ${ }^{85}$ In giving this order, Judge Foster stated that the reason he made it was that the publisher of the Capital had been charging illegal fees. ${ }^{86}$ On January 8 , the Capital commented on this singular order editorially. ${ }^{87}$ On January 9, Judge Foster replied to the editorial in an open letter to the Capital in which he defended his action and threatened the editor with prosecution in his court. ${ }^{88}$ To this there was an appropriate editorial reply. ${ }^{89}$ On January 11, there was served on the editor of the Capital an order of the court giving him three days' notice to appear at the retaxing of printers' fees in thirty-three cases, which was printed and received editorial attention in the Capital on January $12 .{ }^{90}$ On January 14, an order was received by J.K. Hudson from Judge Foster's court stating that the illegal fees charged in the cases retaxed amounted to $\$ 153.60$, and he was given five days (from January 14) to appear and return said money. ${ }^{91}$ To this order there was an editorial reply denying the indebtedness and denouncing the illegal proceedings on the part of the judge. ${ }^{92}$ No further attention was paid to the order. No appearance by an attorney or in person was offered in court at any time during the discussion or since. After publishing the overwhelming verdict of the press against the course of Judge Foster, the case rested without comment or reference by the Capital until the organization of the grand jury for the United States district court, April 14, when Judge Foster made good his threat of presenting the editor of the Capital for indictment, and thus we reach the second trial of this case. ${ }^{93}$

Hudson moved to quash the indictment in Circuit Court. ${ }^{94}$ In that court, Foster and the U.S. Attorney attempted to justify their position, but Judge Caldwell found the reasoning insufficient and found for Hudson. ${ }^{95}$ Once again, Hudson reported the courtroom drama with glee:

\footnotetext{
85. Id. at 8 .

86. Id. at 9.

87. Id. at 8 .

88. Id. at $8-9$

89. Id. at 9-11.

90. Id. at 11 .

91. Id. at 13-14.

92. Id. at $13-15$.

93. Id. at $40-41$

94. Id. at 57 .

95. Id.
} 


\section{JUDGE CALDWELL'S DECISION.}

The following is the decision of Judge Caldwell:

In the circuit court of the United States of the district of Kansas.

The United States of America, plaintiff, vs. Joseph K. Hudson, defendant.

There is nothing in this case that is unusual. The indictment found by the grand jury is presented, and the question has arisen as to whether it charges, with sufficient particularity and distinctness, an offense under the laws of the United States. The question of whether an offense has been committed or not is not before me now. The only question is whether this paper which I hold in my hand charges, in apt and sufficient terms, an offense.

In connection with this transaction, there may have been one or more offenses committed. The question is whether it appears sufficiently on the face of this indictment that any offense was committed by this defendant. To determine that, we must see whether the indictment is sufficiently specific to advise the defendant of the offense with which he is charged; because it is undoubtedly a fundamental rule in criminal proceedings, recognized by all courtsand by none with more distinctness than the federal courts and the supreme court of the United States - that a criminal charge in the shape of an indictment must advise the defendant distinctly and particularly of the offense of which he is accused, and of the particular act or acts alleged to constitute that offense.

To understand the legal value of this indictment, it is essential to understand the law regulating and governing the deposit of moneys in the courts of the United States, and their withdrawal from those courts. In 1871, the Congress of the United States passed an act on this subject. The first section of that act is as follows:

"That all moneys in the registry of any court of the United States, or in the hands or under the control of any officer of such court, which were received in any case pending or adjudicated in such court, shall, within 30 days after the passage of this act, be deposited with the treasurer, an assistant treasurer or a designated depository of the United States, in the name of and to the credit of such court."

That applied to all moneys then in the hands of the clerk, or, in the language of the act, "in the registry of the court," and made it obligatory upon the officers, within 30 days, to deposit the same with the treasurer, an assistant treasurer or a designated depository of the United States, in the name of and to the credit of the court. A designated depository of the United States is a national bank, 
designated by the treasurer of the United States as a bank authorized to receive and pay out the public funds of the United States. All banks have not that authority. The authority to receive the public funds of the United States must come from the treasurer of the United States, in pursuance of an appointment made by that officer. No court, and no officer of a court, can deposit, and no court can authorize its officers to deposit, any fund belonging to the registry of a court, in any national bank except such as may have been designated by the treasurer of the United States as banks that may receive and pay out the funds of the United States.

Having made proper provision for getting all such moneys into a safe place, into the custody of the treasurer, an assistant treasurer or a designated national depository of the United States, Congress then proceeds to legislate for the future. There had been abuses; it had transpired that officers of courts receiving funds had retained them and used them for their private purposes, and when they were wanted they were not forthcoming. This act was passed to correct that abuse. It proceeded, in the first place, to get in, gather together into a safe place, all moneys and funds in the hands of the court, and then it legislates for the future in these terms: "And all such moneys which are hereafter paid into such courts, or received by the officers thereof, shall be forthwith deposited in like manner." That is, with the treasurer, an assistant treasurer or a designated national depository of the United States. "That no money, deposited as aforesaid shall be withdrawn, except by order of the judge or judges of said courts respectively, in term or in vacation, to be signed by such judge or judges, and to be entered and certified of record by the clerk." The clerk has no authority to draw a check. His name as drawer of the check on the treasurer, an assistant treasurer or a designated national depository of the United States, is of no more legal effect or force or validity than the name of the crier of the court would be. It is to be got out by the order of the court or judge, to be signed, by such judge or judges, and entered and certified of record by the clerk; "and every such order shall state the cause in or on account of which it is drawn."

I have read the original act because it throws some light on the revision.

In making the revision, there was only a very slight change made in the language of the original act. Of course the first provision had served its purpose; the 30 days had elapsed, and the first clause of the first section is omitted, but the balance of the act is retained. Section 995 of the Revised Statutes says: "All moneys paid into any court of the United States, or received by the officers thereof, in any cause pending or adjudicated in such court shall be forthwith deposited with the treasurer, an assistant treasurer or a designated depository of the United States, in the name of and to the credit of such court. No money deposited as aforesaid shall be withdrawn except by order of the judge or judges of said courts respectively, in term or in vacation, to be signed by such judge or judges, and to be entered and certified of 
record by the clerk," who does all the recording for the court; "and every such order shall state the cause in or on account of which it is drawn."

Now, I may state here, my practice has been, conforming to that act, to have a printed record, a volume of blank printed orders, leaving the title of the case, the name of of [sic] the payee of the check, and the amount, blank; also leaving space for my name or the name of any other judge that happens to be holding court. Then I have a copy of that which is a record. Having two of these, the original is signed by me and given to the party entitled to the fund; the other is kept, an exact copy, and is entered of record. The clerk attests the record by his signature, and also attests the check, but the check is drawn as required by law, and signed by the judge.

That is the only way that a fund can be got out of the registry of the court when it once goes there - using the term "registry" in the sense in which the learned counsel for the government uses it in this indictment.

The penal provisions of the Revised Statutes are the same in substance that they are in the original act. It first relates to the clerk and other officers of the court: "Every clerk or other officer of a court of the United States who fails forthwith to deposit any money belonging in the registry of the court, or hereafter paid into court, or received by the officers thereof, with the treasurer, assistant treasurer or a designated depository of the United States, in the name of and to the credit of such court, or who retains or converts to his own use, or to the use of another, any such money, is guilty of embezzlement," etc.; and "every person who knowingly received from a clerk or other officer of a court of the United States any money belonging in the registry of such court as a deposit, loan or otherwise, is guilty of embezzlement."

Now, this defendant is indicted under that last section of the act. Before I proceed to test the sufficiency of this indictment, it is necessary to show what may occur. The court may have its funds in a dozen, or, for that matter, a hundred different places; as, for instance, the court over which I have had the honor to preside in Arkansas for 25 years, has moneys now deposited in a national depository at Little Rock - that is, a national bank, designated by the secretary of the treasury to receive a deposit of national funds. It has funds with the assistant treasurer of the United States at St. Louis, and with the assistant treasurer of the United States in New York city, and with the assistant treasurer of the United States in the city of Boston, which are all lawful depositories under the act; three of them assistant treasurers, and one a designated national depository. Now, suppose a man is indicted in the district of Arkansas for unlawfully obtaining money out of the registry of the court. What registry? From the national depository at Little Rock, or from the assistant treasurer at St. Louis, or from the assistant treasurer at New York city, or the assistant treasurer in Boston? I don't know how many depositories the circuit court for this district may have; it may have a great many more, for aught I 
know, or it may have less; but I do know that this indictment don't tell this defendant what depository he is accused of taking this money out of, or what registry; that is very clear. It nowhere appears with sufficient distinctness what depository of this court is meant.

There are very many questions that might be raised as to the sufficiency and particularity of this indictment. The act itself is not charged with sufficient particularity.

Now, "on pretense of false and illegal claim for services for publishing illegal notices." Why, that is nothing; you might have said on pretense of being a handsome man; it would be legally worth as much as that. How does the court know what the pleader thinks is a "pretense of a false or illegal claim?" What does the court understand a pleader to mean by "false pretense," or "on pretense," without stating what the pretense was? One man may think a thing is a false pretense, and another that it is a meritorious and just one. What was the pretense? It is not for the pleader to say it was on false pretense; that is a mere conclusion of law. You must show what he did, in language to this effect: "and that he did make a false pretense in this, to-wit: That, whereas, he had performed a service for which he was entitled to be paid a certain sum of money, to-wit, so many dollars; that he, thereafter, knowingly, fraudulently and willfully made out an account of those services for so many dollars, and presented it, and by a false oath or by some other pretense, induced the court to make an illegal order in his favor, by which he obtained that money from the registry of the court," naming the registry. Or, if the money was not obtained in this mode, then the manner in which it was obtained must be particularly set out. There are other points that might be alluded to, but it is not necessary. It is sufficient to say that this indictment, as it stands, does not sufficiently specify the act done by the defendant. Whether there was an act committed which, if properly set out, would constitute an offense under this section, I do not decide. That is not the point; the court must not speculate upon that. It is a homely phrase, but a good one for the court to follow, not to cross a bridge until you come to it. The only thing the court is called upon to decide is that this indictment is uncertain and insufficient, and that it fails to charge, with sufficient distinctness, an offense under that section.

For that reason the motion to quash will be granted. ${ }^{96}$

The battle between Major Hudson and Judge Foster appeared to be at an end in 1890 when Judge Caldwell quashed the indictment against Hudson. ${ }^{97}$ For the next five years the two men seem to have avoided

96. Id. at 61-62.

97. Id. 
each other. ${ }^{98}$ Hudson continued to edit his newspaper and Foster continued to sit on the federal bench, disturbed only by intermittent bouts of illness. But the peace between them did not last forever. ${ }^{99}$ The battle was rejoined in $1895 .^{100}$ This time, Foster made the first move. ${ }^{101}$ Hudson had attempted to be appointed state printer. ${ }^{102}$ Judge Foster, no doubt still angry about his loss five years before, immediately took steps to block Hudson from his goal. ${ }^{103}$ Once, again, the two men became public adversaries, as seen in an editorial from the Daily Capital on Sunday, June 2, 1895:

\section{THE LEAN AND LANK CASSIUS ONCE MORE.}

We see that Judge Cassius Gaius Foster is very unnecessarily sticking his nose into the state-printer contest. He was not too sick last winter to go to the statehouse to lobby against the election of Major Hudson, although not able to do the work of United States district judge, for which he was drawing full pay. We understand that it is upon Judge Foster's advice that the populist Snow makes a contest for an office he was not elected to fill. This is not the first time the narrow personal prejudices of Judge Foster have run away with what discretion and sense he may have. Once before, when Major Hudson was concerned, he forgot the dignity of his position, and exposed his lack of knowledge of law and justice, in a newspaper controversy over a trial taking place in his own court. To a packed grand jury, this travesty upon a just judge gave such instructions as to insure a verdict against the collection of fees he himself had indorsed as correct in the particular cases under trial, and in similar ones for 15 years before. When the case came to be reviewed by Judge Caldwell, a man of real legal learning and high judicial honor, the petty personal spitework of Judge Cassius Gaius Foster was swept aside, and the legal tyrant's large ears exposed to the ridicule of the people. Since that time he has been engaged in drawing the salary, for which he has not rendered the services it should pay for, and holding on to an office which he has never been large enough to fill, trying through friends to bulldoze the government into retiring him upon full pay. A part of the mission of this judicial cadaver is to follow, with the malice born of small souls, a man who neither feared his power nor respected his ignorance of law. We copy Judge Foster's facetious opinion upon the right of a man to an office whose claim rests, not upon being the choice of a majority of the representatives of the people, nor upon the fact that he was elected at

\footnotetext{
98. Id. at 3.

99. See id.

100. Id. at 3,69 .

101. $I d$. at 69 .

102. See id.

103. Id
} 
all, but upon the supposition of a technical violation of the statutory law in Major Hudson's election. When it is known that the populist majority of the senate, in a caucus the night preceding, agreed to try to prevent the election of a state printer by remaining out of the joint convention, the whole basis of Snow's dishonest claim, advocated by Judge Foster and the anarchist Clemens, fails, because conspiracy to defeat a constitutional duty is neither good public policy nor good law. The following is the profound legal opinion of Cassius Gaius Foster upon a question which involves principles of constitutional rights, of justice to the people's representatives, and the question of the supremacy of the majority, all of which do not seem to be within the view of the judge who is pleading the case of an unprincipled political pirate. The letter is as follows:

Topeka, May 27, 1895.

E. H. Snow: Dear Sir-In answer to your note, asking me to read the letters of Senator Baker and Judge Thacher on the state-printer matter, and if I could express my views on the subject, I need only say, I have read the letters, and summarize their arguments thus:

1. Because the constitution says there shall be a joint convention of the legislature on the third Tuesday of January, to elect a state printer, therefore there was a joint convention.

2. As the law of 1879 requires a majority of the members elected to each house to concur in the election of a printer, it might prevent the dominant political party electing its candidate, therefore the law is unconstitutional.

For several reasons, which suggest themselves to the average legal mind, to say nothing of the decided cases, there is, in my opinion, nothing in either proposition. How would it do to try your side of the case in the courts?

\section{Very truly, C. G. FOSTER. ${ }^{104}$}

This time Hudson had overreached. One simply does not refer to a federal judge as an "unprincipled political pirate." But Hudson probably did not expect what came next. Rather than carry on the battle in the newspaper, Judge Foster turned to the Kansas courts and brought a criminal libel action against Hudson. ${ }^{105}$ The spectacle of a federal judge suing a newspaper editor for libel in a state court was one not seen before

104. Id. at $69-70$.

105. Id. at 70 . 
in Kansas. But odd as the suit may have been, Foster had the law on his side this time. Two suits were brought, one in the Kansas District Court of Shawnee County, and another in Atchison, Foster's home town. ${ }^{106}$ Once again, Major Hudson used his newspaper to defend himself and to attack Foster. But neither Foster nor Hudson really seemed to have had much taste for another major battle like the one they had fought five years before. The case against Hudson opened on September 28 and Hudson's lawyer immediately made a motion to quash. ${ }^{107}$ The two sides argued the motion, but the judge, rather than deciding immediately, took the motion under advisement until the next day. ${ }^{108}$ At that time, District Judge Hazen overruled the motion and set the stage for the trial to begin. ${ }^{109}$ However, it did not do so. Instead, the prosecutor asked for a delay in the proceedings on the ground that Judge Foster was ill and could not appear as a witness. ${ }^{110}$ On October 5, the prosecutor, at the request of Judge Foster, withdrew the charges. ${ }^{111}$ According to Hudson, the judge in the case "complimented the contestants on their good sense." 112 Hudson had apologized to Foster and that ended the matter.

\section{CONCLUSION}

Withdrawal of the libel action in 1895 marked the end of the two epic battles between Foster and Hudson. Foster petitioned Congress just a few years later to be allowed to retire with a pension from the Federal District Court and, as soon as this was granted, he did so. ${ }^{113}$ He soon died. Hudson, on the other hand, continued his journalistic career, although, perhaps, never did he again so deserve the title of "Fighting Joe Hudson," as he did during his struggle with Judge Cassius Gaius Foster.

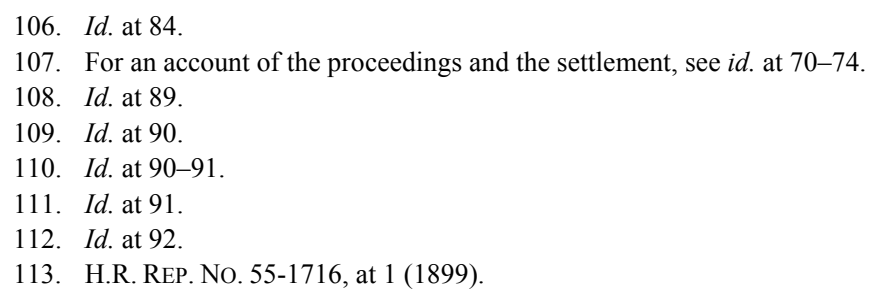

